4. Леонтьев А. Н. Деятельность. Сознание. Личность / А. Н. Леонтьев. М.: Политиздат, 1995. 304 c.

5. Мартиненко С. М. Система підготовки вчителя початкових класів до діагностичної діяльності: дис... д-ра пед. наук: 13.00.04 / Нац. пед. ун-т ім. М. П. Драгоманова. Київ, 2009. $476 \mathrm{c}$

6. Хомич Л. О. Професійно-педагогічна підготовка вчителя початкових класів. Київ: Магістр-S, 1998. 201 с.

7. Якунин В. А. Педагогическая психология: учеб. Пособие / В. А. Якунин; Спб: Полиус, $1998.317 \mathrm{c}$.

\title{
References
}

1. Velykyi tlumachnyi slovnyk suchasnoi ukrainskoi movy [Large interpretive dictionary of modern Ukrainian. (2009). Kyiv; Irpin: Perun.

2. Derzhavna prohrama «Vchytel» [Public Teacher Program]. 28 bereznia 2002 r., № 379. (2002). Official Bulletin of Ukraine, 3, 109-130.

3. Dubovytskaia, T. D. (2001). Psykholoho-pedahohycheskye osnovy lychnostno-znachymoho obuchenyia $\mathrm{v}$ professyonalnoi podhotovke budushcheno spetsyalysta [Psychological and pedagogical foundations of personally meaningful training in vocational training built specialist ]. Bulletin of Orenburg State University, 7, 50-53.

4. Leontev, A.N. (1995). Deiatelnost. Soznanye. Lychnost [Activity. Consciousness. Personality]. Moscow : Polytyzdat.

5. Martynenko, S.M. (2009). Systema pidhotovky vchytelia pochatkovykh klasiv do diahnostychnoi diialnosti [The system of preparation of elementary school teachers for diagnostic activity]. (The dissertation of Doctor of Pedagogical Sciences). National Pedagogical University. MP Dragomanov, Kyiv.

6. Khomych, L. O. (1998). Profesiino-pedahohichna pidhotovka vchytelia pochatkovykh klasiv [Vocational and pedagogical training of primary school teachers]. Kyiv: Mahistr-S.

7. Iakunyn, V.A. (1998). Pedahohycheskaia psykholohyia [Educational psychology]. St. Petersburg : Polyus.

УДК 81'37-047. 37(045)

DOI:10.31339/2617-0833-2019-2(27)-2-75-86

\section{THEORETICAL COMPREHENSION OF THE NATURE AND STRUCTURE OF THE LEXICAL AND SEMANTIC FIELD IN MODERN LINGUISTIC RESEARCH}

Prokopovych Lidia, Bopko Ihor

\section{ТЕОРЕТИЧНЕ ОМИСЛЕНЯ ПРИРОДИ Й СТРУКТРИ ЛЕКСИКО-СЕМАНТИЧНОГО ПОЛЯ В СУЧАСНИХ МОВОЗНАВЧИХ ДОСЛІДЖЕННЯХ}

Прокопович Л С., Бопко I.3.

The theory of lexical - semantic field as a paradigmatic phenomenon has been theoretically substantiated in the article; the scientists' views of on this issue have been analysed; a generalized review of the history of the nature and structure of the field theoretical comprehension has been conducted. Discussion issues of modern field theory have been distinguished - the main features and structure of LSF. Modern types of classifications have been considered, those based on the relationship types and on the relationships between the field components. Particular attention has been paid to the issue of the nucleus and the periphery of the word in the field structure.

Key words: lexical and semantic field, distribution, morphosemantic field, syntagmatic field, 
associative field, core, periphery.

У статті теоретично обтрунтовано теорію лексико-семантичного поля як парадигматичного явища; проаналізовано погляди вчених на ию проблему;здійснено узагальнювальний погляд на історію теоретичного осмислення природи й структури поля. Виокремлено дискусійні питання сучасної теорії пол я-основні ознаки й структуру ЛСП. Розглянуто сучасні типи класифікащій, як на основі типів відношень так і на основі зв'язків між компонентами поля. Особливу увагу приділено проблемі ядерності та периферійності слова в структурі поля.

Ключові слова: лексико-семантичне поле, дистрибуція, морфосемантичне, синтагматичне, асоиіативне поле, ядро, периферія.

It is known that the systematicity of the vocabulary of the modern language is manifested in all its elements: in the organization of thematic lexical groups, in the structure of the polisemantic word with its separate lexical and semantic variants (LSV) and links with other elements of the lexical structure - synonymic groups, antonymic pairs, etc. "[19, 24].

The task of the researcher is to identify, organize and describe this system. From this viewpoint, one of the most productive today is the field structuring technique.To partial linguistic methods belong: the method of semantic and stylistic analysis, the method of comparison, quantitative and statistical method.

The necessity, stimulated by the advancement and development of the concept of "inner form of language" (suggested by W. Humboldt) and the works of German linguists (J. Trier, G. Ipsen, A. Jolles, W. Porzig, W. Wartburg) concerning the development of the concept of "semantic field", to develop general principles of word meanings classification.Based on the basic tenet of W. Humboldt's theory, J. Trier substantiated the method of semantic field (SF) as a method of generalizing relations in the vocabulary. The concepts existing in the language he systematizes by into more or less closed groups ("blocks"), within each of them the concept (meaning) exists only because of its correlation with other concepts (meanings). The loss of a certain concept or its transformation causes the restructuring of the relations between the components of the group. In addition, J. Trier argued that the so-called lexical and conceptual "gaps" can only be traced when comparing the language with another one, since each language in its own way, represents and reflects the world. The semantic fields are hierarchically interrelated. The set of all fields comprises the lexical-semantic system of language.

The ideas, formulated in the writings of J. Trier, stimulated the activation of the studies of the lexical system of language. [23]. They removed restrictions concerning the words, that belong only to one field and cover material exclusively registered entities (L. Weisgerber, O. Ducháček, W. Porzig); also denied the thesis about the hermetic nature of the field (A. Jolles), the importance of context in determining the meaning of the field constituents has been emphasised (K. Reuning).

J. Trier's theoretical ideas received productive development in the works of W. Porzig, who characterized this type of vocabulary grouping through the defining types of relationships that arise due to the systematic combinability of words in the process of language functioning. Besides, W. Porzig motivates the expediency of the semantic field modelling, taking into account the semantic relations of different parts of the language, including verbs and nouns, adjectives, etc. The extension of this idea in the works H.S. Shchur, who considers it expedient it in one semantic field to "consider [...] the union of lexemes on the basis of a common differential feature, that represents interclass relations of the tyре червоний - червоніти - червоно» [27].

Among the theoretical substantiations of the field as a paradigmatic phenomenon, the concept of E. Coșeriu deserves attention. The scientist defines a lexical (or verbal) field as a set of lexemes, combined by a common lexical entity and opposing the minimal differences of that entity. He recognizes the existence of conceptual and associative fields alongside with the lexical ones. Associative fields are different from lexical ones because they are centrifugal, while lexical fields 
are centripetal in nature.

An important stage of deepening the theory and developing techniques for practical systematization of vocabulary by the method of field structuring are represented in the works of V. Vynohradov, F. Filin, Yu. Apresian, H. Shchur, V. Hak, A. Ufimtseva, Yu. Karaulov,F. Zhylko, A. Buriachok, V.Rusanivskyi, L.Lysychenko, O.Bondar, L.Pustovit,V. Diatchuk L. Savchenko O. Malenko L. Mialkovska etc. Thus, the basis of the theoretical substantiation of the field in the works of F. Filin, is the oppositeness of lexical and semantic and thematic groups, built on the similarity / dissimilarity of semantic relations of words or extralinguistic ties between objects, phenomena of reality [25]. This gives reason to assign to a semantic field (as a lexical union with homogeneous, correlative meanings) synonyms, antonyms, and other groups of words, bound by semantic relations.

Yu. Apresyan connects the concept of semantic field with distributive meaning and frequency models. Under the term distribution, the scientist understands the structural model of words, used in a particular meaning, and the word combinability in this meaning. According to his viewpoint, structural models and combinability formulae "have certain typical meanings", and therefore allow to stratify the language vocabulary objectively into certain semantic homogeneous groups (semantic fields) [2].

H. Shchur defined the field as a model of systematization of language lexical units with common invariant features [27].

Generalizing the properties of the semantic field, defined in modern linguistic literature, Yu. Karaulov focuses on the orderliness of the field elements and their relationships. This gives the scientist reasons to state the autonomy of the semantic field, which is determined by its integrity and fundamental isolation [12].The author also emphasizes that the lexical and semantic field is a capacious concept that syncretises the main problems of lexicology (synonymy, antonymy, polysemy, hyper-hyponymy and partonymy), terminologizes the problem of word and concept correlation.

Aim of the article - theoretical comprehension of the nature and structure of the lexical and semanticfield in modern linguistic research.

In the course of the research the following methods have been used: descriptive analysis, generalization, systematization in the processing of scientific literature and dissertations to determine the state of development of the problem under study as well as the comparative analysis of different authors' approaches.

In modern Ukrainian linguostylistics, the field is interpreted as "a set of linguistic units, predominantly lexical, united by a common sense, by a single concept, by the functional similarity of marked phenomena" [24]. Since the semantic field can combine words (different parts of speech) with at least one common meaning concerning the headword, its structure should be considered taking into account semantic differential features and oppositions (L. Lysychenko, N. Bobukh, L. Savchenko, O. Rud).

Lysychenko L. characterizes lexical and semantic field "as a collection of words and meanings that cover a certain segment of reality". It is a large grouping of LSV that are related to a single segment of reality and belong to different parts of speech [14].

A generalized look at the history of theoretical comprehension of the nature and structure of the field suggests that the corresponding issues were initially developed in two directions: a) extralinguistic - in the perspective of investigation of conceptual fields, conceptual language content for revealing of the native speakers' spiritual world and national character originality (L. Weisgerber, J. Trier). The classification of units in this case implies a logical type of word grouping, because it reflects the epistemic logic of the world; b) linguistic, which consisted in the study of the vocabulary composition of the language in different lexical and semantic groups, synonyms (G. Ipsen, W. Portzig, A. Jolles, K. Reuning, Yu. Apresyan, A. Kuznetsov, A. Ufimtseva).

The modelling in this case is carried out not by conceptual, but by linguistic parameter, since the semantics of the word is entirely caused by the relations formed within the oppositions of the 
word by other components of the same field (I. Kobozieva,Ye.Komarov, L.NyzhehorodtsevaKyrychenko).

Therefore, modern researchers emphasize that the study of lexical fields with the usage of only logical or only linguistic approach - is unproductive in terms of understanding the language as a holistic system, the structure and functions of which are determined by the dynamic set of factors of lingual (reflecting immanent linguistic regularities) and extra-lingual (due to the objective nature of reality, which is reflected in language).

Nowadays, the field method is recognized as one of the most productive for the systematic representation of units of different language levels - phonetic, lexical and phraseological, syntactic, semantic.

The advancedtheoretical division of fieldsadequately correlates with such assumption: in addition to the already mentioned lexical ones, researchers "distinguish grammatical, morphosemantic, syntagmatic, as well as associative fields, formed by combining word-associates around a word-stimulus"[12, 131].At the same time, the usage of the field methodis becoming more and more relevant for the inter-level, functional study of linguistic phenomena, which leads to the isolation of functional and semantic fields (M.Hukhman, O.Bondarko,M.Vsevolodova)

In particular, O. Bondarko defines the functional and semantic field as a binary unity formed by grammatical (morphological and syntactic) means of language together with lexical, lexical and grammatical and word-forming elements that interact with them and belong to the same semantic zone. The main features of the functional-semantic field, according to the researcher, are: 1) the presence of common invariant semantic functions in the elements that form this group; 2) interaction of both homogeneous and heterogeneous elements, including grammatical and lexical ones; 3) a structure in which the "center (core) - periphery" members play a decisive role, the gradual transitions between the components of this grouping and other groupings, partial overlaps, common segments, systemicboundaries.

The main features and structure of LSF are among the discussion issues of modern field theory.

In Ukrainian linguisticsthe term "field" denotes complex functional systemic and structural formation of the lexical and semantic level, represented by a set of linguistic (mainly lexical) units, united by content (sometimes on the basis of formal indicators) and reflecting conceptual, presentational orfunctional similarity of the marked phenomena.The semantic paradigmatic relationships do not only shape its structure (I. Kobozieva, F. Filin), but also the semantic specificity of its various structural levels, the semantic accents of a wordgroup, the prevalence of certain meanings can be find out the on basis of its analysis, due to the fact that LSF is a semantic description made according to a special scheme (M. Nikitin, L. Novikov, Yu. Stepanov, H. Ufimtseva). The important here is the concept of integrated (combining) and (differential) distinguishing features (M. Kronhauz).

Semantic Field (SF) is the most voluminous onomasiological and semasiological hierarchically organized grouping of lexemes that are systematizedaccording to one generic meaning and represent a particular semantic sphere. Onomasiological interpretation of the field is based on the generic seme (hypersemic)presence in its structure, which denotes the class of objects. Semasiological characteristic of a field is that its components are correlatedaccording to the integraldifferential features. This allows to combine and differentiate them in the boundaries of one semantic field.

An important question of LSF theory is the relation between the components of the field, predetermined by its parameterization as a complete microsystem. The basis of the relations in the semantic field are lexical meanings of words. Relationships between elements of a field are shown as the relation of identity (sameness) and differentiation (difference or contrast). These relations are realized taking into account the smallest and indivisible (elementary) lexical values (semantic differential features), the latter being the basic concepts in the analysis of the lexical-semantic level elements and units. 
There are four main types of relations (oppositions) have been marked in modern research (L. Novikov, L. Vasyliev, Yu. Karaulov, L. Lysychenko, L. Savchenko, L. Kravets, Zh. Marfina, I. Hotsynets): zero (full identity correlation), privative (inclusion correlation; form the structural framework of any system), equipolent (over lapping correlation), disjunctive (difference correlation). They provide the formation of field lexical and semantic structures (Yu. Karaulov).This thesis logically extends V. Vinogradov's view that "notional phenomena in language form internally connected series based on a common element or feature andprimarily correlate within the boundaries of these series. These rows [..] are members of higher level rows [..], not only correlated but also interconnected and interdependent» [8].

The scientists identify the following types of relationships between field components according to another type of classification: 1) hyper-hyponymy (successive inclusion of some generic paradigms into the other ones: колір-червоний); 2) overlapping (words have common and differential semes); 3) synonymy; 4) draduation (synonyms are called different degrees of notion designation: холодниц - прохолодний - теплий - гарячий); 5) partitive connection(the correlation of the part and the whole, e.g.: рука - кисть - палець);6) antonymy; 7) conversibility (word pairs that characterise the same situation from opposite perspectives:купувати - продавати);8) incompatibility (existing between cohyponyms having the common hyperonym:блакитний - червониц - зелений.The worddenotata do not overlap; their significatum have a common part - the set of features that form the signifier of the common hyperonym); 9) agency (the doer of the action: куnувати nокуnеuь ) (I. Kobozieva, Ye. Komarov)

The peculiar attention to the type of relations between the components of the field is explained by the fact that they are important for determining its structure: center (field name), core (most informative part of the field), juxtaposition zone and peripheral zone (near and far, which differ in the degree of distance from the core). The units with the most abstract meaning are the field name and core. According to L. Lysychenko, the coreis represented by a set of lexical and semantic variants that "most fully express the essence of the field" [15].

The periphery, on the contrary, is formed by lexemes, more distant from the field name, such as occasional, figurative linguistic and aesthetic modifications, which can enter into other semantic fields and compile "systemic boundaries" (V. Hak's term) with certain semanticsigns. Synonymic and antonymic rows create their own microfields within the SF.

Cf. also the opinion of A. Antomonov, who states that the core of the SF contains elements that associatively correlate only with the elements of this field, and the periphery of one field may be the core or even the name of another field [1].

The core or periphery of a word in the structure of a field can determine the complexity of its semantic structure: "the smaller the number of semes in a sememe, the more abstract and closer to the nucleusit is" [19]. The core lexeme often serve as an identifier in dictionary definitions.

Many scholars believe ( M. Kocherhan, V. Levytskyi, Yu. Karaulov) that the status of core // periphery of lexeme within a certain LSF can be stated by the frequency of its usage. Cf.: "The frequency criterion should be considered as the main criterion for determining the location of a lexical unit in a lexical and semantic group" [19]. That is, the core of the LSF is the most commonly used (most frequent) and the most informative words that are bearers of the basic meanings.

The periphery of the lexical microsystem is also not homogeneous and is subdivided into the zones of the near, far, and extreme periphery.

The near periphery includes unambiguous elements that are almost not dependent of the context; the far periphery is formed by non-frequent, ambiguous, semantically context-dependent words, which usually have one functional seme and are characterized by narrower differential features; the extreme periphery includes components with extremely low frequency and significantly context-dependent. According to the core archiseme, such lexeme belongs to another field, but due to the peripheral seme is included intothis field. Thus, the peripheral components have much weaker semantic links than the core components and, when located at the boundaries of different semantic 
fields, may find different correlations with them.

In the overlapping of different fields, common segments are formed, as well as the chains of gradual transitions between the core and the periphery, which are in constant dynamics and interaction.

The systematic nature of vocabulary is manifested in the connection of words that form different semantic subsystems. According to the correlation feature of lexemes with extra-lingual reality, these subsystems are differentiated into thematic groups (TG), which are divided into subgroups, microgroups, and individual nominations of this or that objects, and according to the nature of the relationship between the lexical units themselves - into LSGs (synonyms, antonyms, hyper-hyponomic constructs, etc.) [6].

V. Levytskyi investigated the regularities of establishing and detecting structural and semantic relations within the lexical microsystems. Heincluded semantic fields, LSG, synonyms, antonyms, thematic groups, associative fields, hyponymic groups into systemic vocabulary units.

The scientist emphasizes the extralinguistic factors of the formation of the following units:"the environmental relations are projected "vertically "on a lexical system, dividing it into interconnected lexical blocks" [13].

The above list is afflicted by a certain mix of different lexical groupings, which is characteristic of many contemporary works, cf.: the term"field"is often used undifferentiated, along with the terms "lexical and semantic group"and"thematic group of words".Explaining the essence of such terminological uncertainty, D. Ishchuk notes that"this is the problem of correlation of the concept and word meaning, the problem of designing extralinguistic relations and relations between objects and phenomena on the lexical system of language, where exist their own, internal, intralinguistic relations and correlations" [11]. That is, since there are no clear criteria for determining the "lexical and semantic field", "lexical and semantic group", "thematic group", their theoretical and practical distinction belongs to the actual aspects of Modern Ukrainian linguistics, in particular linguostilistics.

In Modern Ukrainian linguostilistics the terms "lexical and semantic field" (LSF) and"lexical and semantic group" (LSG)correlateas a broader and narrower concept.

LSG - is systematized wordgrouping due to the presence of immanent ties of the lexical meaning.Its components are unitedby a semantic invariant and are differentiated by a differential component (seme or semes).

That is, LSG is a fragment of LSF structured according to the principles of the semantic field, but differs from it with a certain limitation and relative isolation (V.Krasavina, O. Petrushenko).In general, the issue of the correlation of LSPF and LSG is solved in the perspective of hyper-hyponymic relationships.

In the context of the field approach, LSGs are considered as microfields within the LSP, since the meanings of the LSP elements are united by an integrative generic seme, and the meanings of the LSG elements are distinguished due to one of the aspective semes.

The interpretation of LSG is advanced by A. Buriachok. He points out that there are relations between LSG components of synonymy, antonymy, specification, differentiation of close and adjacent meanings, etc. [6].

The systematization of modern views on the nature and criteria for the isolation of LSG shows several typological characteristics:1) the presence of core (basic, main) and peripheral subgroups (Yu. Apresian); 2) allocation within the LSG, depending on its specific content characteristics of paradigmatic rows (semantic rows, paradigms and sub-paradigms) with genericspecies or species-specific types of relations; 3) the presence of several "stylistic layers" in the structure of LSGs (N. Mekh).

A broader variant of vocabulary unity is the thematic group (TG), which is formed "according to the content of the signified concepts, that is, by topics and spheres of usage, almost irrespective of the relation of the words to each other by their meaning" [13,5]. Units are not assigned to a certain TG like to LSF. The assignment to TG is based on the classification of the 
objects and phenomena themselves, taking into account the denotative meaning and the common features of the phenomena of reality, but not of the lexical and semantic relations ( $\mathrm{F}$. Filin, L.Lysychenko, L.Vasyliev). Generally, the components of TG "are united by a typical situation or topic, but a common identifying (core) seme is not required for them" [7], that is, the nature of their relationship is extralinguistic.

According to F. Filin, theisolation TG, their component content depend on: the level of knowledge of the nation as the creator and language bearer, the ability of the nation to classify the phenomena of realitythat have dictionary naming units.

Elaborating the issues of structuring and hierarchy of TG, D. Shmelov states that this systemic vocabulary grouping is based on the objects and phenomena classification and is subdivided into smaller units (fields, LSG).

V. Kodukhov considers that TG has the distributive feature - is formed by units of different parts of the language, because the dominant status reserved by the nouns, in which the denotative component prevails over the significative one. LSG and TG are correlated to LSF as part of its structure. Through them, the semantic fields overlap each other, forming the integral structures.

Improvement and advancement of the field structuring technique produced a terminological specification of concepts connected to the practical application of the appropriate methodology. This manifested itself in the designation of the concept of microfield - "lexical and semantic unity, in which the core is expressed by a word with partial meaning in comparison to the core [..]. Being a part of the field, the microfieldis semantically and structurally subordinated to it" $[2,45]$. According to L. Vasyliev, the term field is correlatedto the notion of lexical and semantic group in genericspeciesrelations, as general corresponds to specific [7]. A lexical semantic group is understood as a set of words that belong to one part of speech and can be combined based on of a word, by a common seme in other words, to that one word: on a common lexical and semantic concept expressed in all words (e.g. bird names); on a distinctive feature (in the very name); lexical unities with homogeneous, juxtaposed meanings, reflecting the specific language phenomenon, predetermined by the progress of historical development; a class of words belonging to a part of speech having the sufficiently general integral semantic component (or components) and typical specifying (differential) components, as well as those components characterized by similar combinability and wide range of functional equivalence and regular multiplicity, have rather logical or conceptual character, than the linguistic one.

It is common knowledge, thata word is an element of a field, it may be monosemantic or a lexical and semantic variant of a polisemantic word. The integral feature, within the semantic structure of the word, may not be present in all its variants. So, we can speak about two types of fields in the lexical and semantic system: 1) lexical (denotative, thematic, onomasiological, subjectconceptual); 2) lexical and semantic (paradigmatic). In each semantic row of the lexical and semantic system there is a semantic field - the interconnected lexical units, each of which is characterized by a common concept. LF, which unites words on a subject-conceptual basis, the invariant of which is an extralinguistic phenomenon (denotatum or denotata, significatum or plurality of them), and which data are organized on the center - periphery principle [2, 4], as well as LSF that is specific in nature and integrates directly words that have paradigmatic and syntagmatic characteristics.

Studies of linguists have shown that the main properties characterizing the SF are: the relationship of its elements (words or their individual lexical and semantic variants); the systemic nature of these connections; the interdependence and definiteness of the field elements, that emerge from its internal arrangement; relative autonomy of the field, which is expressed in its integrity; the continuity of the namingof its semantic space and the interrelation of semantic fields throughout the dictionary.

The methodology of the vocabulary division into lexical and semantic fields (LSF) through field structures has been thoroughly elaborated, in the process of the language system studying. It helps to fix in the language a sufficiently limited fragment of reality. 
The term field in this study means: 1) field is an inventory of elements that are linked by systemic relationships; 2) the elements forming the field have semantic unity and perform a common function in the language; 3 ) the field has a special structure (the core, the periphery), which is characterized by the maximum concentration of features in the core and the incomplete set of these features with the possible weakening of their intensity at the periphery. The core constituents are the most specialized for performance of the field function. These are the obligatory members of the field and are the most frequent. The boundary between the core and the periphery, as well as between the zones of the field, is unclear. LSGs are paragon field structures, since the gradation of the periphery zones is specified on the example of various types ofLSGs; 4)field constituents may belong to the core of one field and to the periphery of another field or several fields; 5) different fields overlap, forming gradual transition zones, according to the law of the field organization of the language system. The LSF integrates the meanings of the word-elements of the horizontal structure of the language system.

An invariant in LSF is an abstract general semantic word system that varies with field constituents, which in their turn vary one another and is defined as a series of paradigmatically related words that share a semantic feature and differ in, at least, one differential feature.

Depending on the degree of abstraction of the name of the lexical and semantic field, there are two types of LSFs, namely: a) grammatically homogeneous fields based on the part of speech grouping, their constituents belong to one specific part of speech and are grouped only because of the similarity of their part of speech semantics.

The studies of verb, noun [16; 17], adjective [18] fields, etc. are especially popular among the first field type. Scholar Yu. Apresian emphasizes on the role of invariant meaning, which integrates words of different parts of speech into one LSP [2].

L. We is gerber acknowledges that LSFis formed by means of the words of different parts of speech, which are related to each other by both semantic and word-forming correlations. R. Haisyna considers inter-parts of speech semantic fields the largest units of the lexical and semantic language system, which promote the semantic systematization of grammatically heterogeneous material [10, 23].Since LSF is characterized by the constant homogeneity of units, therefore, polisemantic words must differ in their conceptual affiliation to different fields. Therefore, the working lexical unit is the lexical and semantic variant (LSV) as an elementary unit that does not exist in the language in isolation. LSV connected to a relatively stable relationship and constantly interacting within the LSF. Being a lexical microsystem, LSF is also endowed with autonomy, independency in the lexical and semantic language system [5, 77]; integrity, completeness [9] and specificity in different languages. Thesaurus dictionaries reflect the systematization of the vocabulary, distinguished on a conceptual basis, into LSFs.

The classification of words in this approach is a logical type of word grouping because it reflects the human epistemic logic.

The logical and linguistic aspects of the structure of semantic fields are analysed in the works of Yu. Karaulov, who notes that the lexical-semantic field is a capacious concept, in which the main problems become entangled and are solved by lexicology (synonymy, antonymy, polysemy), and problems of correlation of word and concept. The study of lexical fields using a logical or linguistic approach alone is inefficient [11]. Thus, LSF is a complex organic entity capable of relative selfdevelopment; it is an element of the linguistic picture of the world (hierarchical structural unity of interconnected and interdependent lexical elements, endowed with a common semantic feature that reflects the conceptual, presentational or functional similarity of the defined phenomena);itis a way of reflecting the system of the dictionary compilation; it is a dynamically developing system linked to the semantic fields of a particular language.

The fact that lexical and semantic fields in vocabulary cause the greatest differences of interpretations is explained, on the one hand, by the presence of weaknesses in the theory of the semantic field itself, and, on the other, by difficulties emerging in the study of the systemic and structural organization of the language vocabulary. Undeniable fact that the lexical and semantic 
field is a structural unit of the lexical level and one of the manifestations of paradigmatic relations in the vocabulary.

Thus, since the purpose of the field approach is to establish linguistic semantic functions embedded in the linguistic system that convey semantic differences in different communicative situations, and the degree of participation of morphological and lexical categories in the transmission of "new" semantic, previously not found oppositions. This also enablesto take into account the provisions on the significant role of content in relation to the form, on the great activity of content in the process of development of phenomena, as well as the possibility of some mutual influence of form and content. The field approach successfully realizes all possibilities of systematic study of language material, clearly defines the criteria of analysis. The specificity of the lexical and semantic system is that it is conditioned by the categories of the material world, social factors.

Changes in vocabulary are manifested in the loss of meaningful parts of obsolete words, the appearance of new words, rethinkingand the formation of new meanings in already known words. This process is in constant progress that is why we can speak about the openness and special mobility of the lexical composition, the signs of transitions happening within the lexical system and subjected to its internal laws and organization.

Therefore, the purpose of field structuring is to identify and stratify vocabulary that covers a certain conceptual sphere and to identify the core components of this system, to establish semantic links between its components, and between this field and other fields. The field method is recognized as one of the most productive for the systematic representation of units of different language levels phonetic, lexical and phraseological, syntactic, semantic. In addition to the already mentioned theoretical field subdivision modern researchers distinguish between grammatical, morphosemantic, syntagmatic, as well as associative fields, formed by combining word-associates around a wordstimulus.

Further studies will be devoted to the implementation of the field method for the inter-level, functional study of linguistic phenomena, which determines the separation of functional and semantic fields.

\section{Список використаних джерел}

1. Антомонов А.Ю. Исследование структурной организации лексико-семантического поля : автореф. дисс. на соискание научной степени канд. филол. наук : спец. 10.02.01. - K., 1987. - $16 \mathrm{c}$.

2. Апресян Ю. Д. Интегральное описание языка и системная лексикография / Ю. Д. Апресян // Избранные труды. - М. : Издат. фирма вост. лит., 1995. - Т. 2. - 766 с.

3. Арнольд И. В. Стилистика. Семантика / И. В. Арнольд. - М. : Наука, 1984. - 300 с.

4. Аскерова I. А. Семантичне поле назв емоційно-афективних станів у польській мові : дис. ... канд. філол. наук : 10.02.03 / І. А. Аскерова. - К., 2006. - 206 с.

5. Ахманова О. С. Основы компонентного анализа / О. С. Ахманова. -М. : Изд-во МГУ, 1969. $-98 \mathrm{c}$.

6. Бурячок А.А. Принципи моделювання семантичних полів лексики / А.А.Бурячок // Мовознавство. - 1985. - №4. - С.41-47.

7. Васильев Л.М. Теория семантических полей / Л.М.Васильев // Вопросы языкознания. 1971.- №. 5. - С.105-113.

8. Виноградов В.В. Об омонимии и смежных с ней явлениях / В.В.Виноградов // Исслед. по русской грамматике. - М., 1975.- С.295-312.

9. Денисов П. Н. Методы семантических полей в лексических классификациях / П. Н. Денисов // Теория поля в современном языкознании : в 2-х ч. Ч. 1. - Уфа : Башкир. унт, 1991. - С. 14-17.

10. Гайсина Р. М. Сопоставительное описание лексических полей (на материале разносистемных языков) : учеб. пособие / Р. М. Гайсина. - Уфа : Башк. ун-т им. 40летия Октября, 1990. - 67 с. 
11. Ищук Д.Г. Лексико-семантическое поле как выражение концептуальной модели времени в языке (на русско-славянском материале) : автореф. дисс. на соискание науч. степени канд. филол. н. / Д.Г.Ищук. - СПб., 1995.-22,[1] с.

12. Караулов Ю.Н. Общая и русская идеография / Ю.Н. Караулов. - М. : Наука, 1976. $355 \mathrm{c}$.

13. Левицкий В.В. Типы лексических микросистем и критерии их различения / В.В.Левицкий // Филологические науки. - 1988. - № 5. - С.66-74.

14. Лисиченко Л.А. Лексико-семантична система української мови / Л.А.Лисиченко. - Х.: ХДПУ ім. Г.С.Сковороди, 1997. - 129 с.

15. Лисиченко Л.А. Мовна картина світу й стан мови / Л.А.Лисиченко // Мировая культура : Традиции и перспективы : [междунар. сб. науч. исслед.].- К.; М.; Херсон : АПН Украины ; ММГА ; ХМИБ ; ХГПИ им.Н.К.Крупской, 1995. - Т.1.- С.13-18.

16. Малімон Л. К. Системні та функціональні характеристики іменників на позначення часу в сучасній англійській мові : дис. ... канд. філол. наук : 10.02.04 / Л. К. Малімон. - Луцьк, 1999. - 351 с.

17. Мосьпан Е. П. Поле собирательных существительных в русском языке : дис. ... канд. филол. наук : 10.02.02 / Е. П. Мосьпан. - Харьков, 2001. - 172 с.

18. Петришин М. Й. Семантичне поле прикметників розміру у старогрецькій мові : дис. ... канд. філол. наук : 10.02.14 / М. Й. Петришин. - Львів, 2005. - 209 с.

19. Полевые структуры в системе языка / под ред. З. Д. Поповой. - Воронеж : Изд-во Воронеж. ун-та, 1989. - 198 с.

20. Савченко Л.Г. До питання про семантичне поле поетичної лексики // Українська мова : історія і стилі / Л.Г.Савченко. - Харків : Основа, 1992.- 148 с

21. Соссюр Ф. де. Курс общей лингвистики / Ф. де Соссюр // Труды по языкознанию. М.: Прогресс, 1977. - С. 31-273

22. Сусов И. П. Системные связи между единицами лексикона [Электронный ресурс] // Введение в теоретическое языкознание / И.П. Сусов. - Режим доступа: https://refdb.ru/look/1364945.html.

23. Trier J. Der deutsch Wortschats un Sinnbezik des Verstandes / J. Trier. - Heidelberg, 1931. $-520 \mathrm{p}$.

24. Українська мова: Короткий тлумачний словник лінгвістичних термінів / [С.Я. Єрмоленко, С.П. Бибик, О.Г. Тодор / за ред. С.Я. Єрмоленко]. - К. : Либідь, 2001. -224 c.

25. Филин Ф.П. О лексико-семантических группах слов / Ф.П.Филин // Языковые исследования. - София, 1957. - С.5-9.

26. Щебликіна Т.А. Роль параметричних прикметників із просторовою семантикою у формуванні лінгвального образу світу : автореф. дис. на здобуття наук. ступеня канд. філол. наук : спец. 10.02.01 «Українська мова» / Т.А.Щебликіна - Харків, 2001. - 16, [1] c.

27. Щур Г.С. Теории поля в лингвистике / Г.С.Щур. - М.: Наука, 1974. - 256 с.

\section{References}

1. Antomonov,A.Yu.,1987. Issledovaniye strukturnoy organizatsii leksiko-semanticheskogo polya [Study of the structural organization of the lexical-semantic field]: Candidate of philological sciences. Kyyiv, 16p.

2. Apresyan, Yu. D.,1995. Integralnoye opisaniye yazyka i sistemnaya leksikografiya [Integral description of the language and systemic lexicography]. M. : 1995. - vol. 2. - 766 p.

3. Arnold, I. V.,1984. Stilistika. Semantika [Stylistics. Semantics]. M. : Nauka.- 300 p.

4. Askerova, I. A., 2006. Semantychne pole nazv emotsiyno-afektyvnykh staniv u polskiy movi [Semantic field of names of emotional-affective states in Polish]: Candidate of philological sciences. Kyyiv, 206 p. 
5. Akhmanova, O. S.,1969.Osnovy komponentnogo analiza [Fundamentals of component analysis]. M. : Publishing House of Moscow State University, 98 p.

6. Buryachok, A. A., 1985. Pryntsypy modelyuvanny asemantychnykh poliv leksyky [Principles of modeling of semantic fields of vocabulary].Movoznavstvo [Linguistics]. vol.4. pp.41 - 47.

7. Vasyliev, L.M.,1971.Teoriya semanticheskikh poley [Theory of semantic fields]. Voprosy yazykoznaniya [Questions of linguistics]. vol.5. pp.105 - 113.

8. Vynohradov, V.V., 1975.Ob omonimii i smezhnykh s ney yavleniyakh[On homonymy and related phenomena]. Issledovania po russkoy grammatike [Studies in Russian grammar.]. pp.295-312.

9. Denysov,P. N.,1991. Metody semanticheskikh poley $v$ leksicheskikh klassifikatsiyakh [Methods of semantic fields in lexical classifications]. Teoriya polya $v$ sovremennom yazykoznanii [Field theory in modern linguistics]. Ufa: Bashkir University.vol. 2. pp. 14-17.

10. Haisyna, R. M., 1990. Sopostavitelnoye opisaniye leksicheskikh poley (na materiale raznosistemnykh yazykov) [Comparative description of lexical fields (based on the material of diverse systems)]. Ufa: Bashkir University.67 p.

11. Ishchuk, D. H., 1995. Leksiko-semanticheskoye pole kak vyrazheniye kontseptual'noy modeli vremeni $v$ yazyke (na russko-slavyanskom materiale) [The lexical-semantic field as an expression of the conceptual model of time in a language (on Russian-Slavic material)]: Candidate of philological sciences. St.P, 22 p.

12. Karaulov,Yu. M., 1976. Obshchaya $i$ russkaya ideografiya [General and Russian ideography].M. : Nauka, 355 p.

13. Levytskyi, V.V. 1988. Tipy leksicheskikh mikrosistem $i$ kriterii ikh razlicheniya [Types of lexical microsystems and criteria for distinguishing them]. Filologicheskiye nauki [Philological sciences].vol. 5. pp. 66-74.

14. Lysychenko, L.A., 1997. Leksyko-semantychna systema ukrayinskoyi movy [The lexicalsemantic system of the Ukrainian language]. KH. : Publishing House of KHDPU named after H. Skovoroda, $129 \mathrm{p}$.

15. Lysychenko, L.A., 1995. Movnakartinasvituystanmovi [The linguistic picture of the world and the state of language]. Mirovayakultura :Traditsiiiperspektivy [World culture: Traditions and perspectives] K.; M.; Kherson. vol. 1. pp. 13-18.

16. Malimon, L. K.,1999. Systemni ta funktsionalni kharakterystyky imennykiv na poznachennya chasu v suchasniy anhliyskiy movi [Systemic and Functional Characteristics of Nouns for Time Marking in Modern English]: Candidate of philological sciences.Lutsk. $351 \mathrm{p}$.

17. Mospan, E. P., 2001. Pole sobiratel'nykh sushchestvitel'nykh v russkom yazyke [Field of collective nouns in the Russian language]: Candidate of philological sciences. Kharkiv. $172 \mathrm{p}$.

18. Petryshyn, M. Y., 2005. Semantychne pole prykmetnykiv rozmiru u starohrets'kiy movi [The semantic field of adjectives of size in Ancient Greek]: Candidate of philological sciences. Lviv, 209 p.

19. Popova, Z. D., (ed.) 1989. Polevyye struktury v sisteme yazyka [Field structures in the language system].Voronezh: Publishing house of Voronezh University.198 p

20. Savchenko, L.H., 1992. Do pytannya pro semantychne pole poetychnoyi leksyky[On the semantic field of poetic vocabulary]. Ukrayinska mova : istoriya i styli [Ukrainian language: history and styles]. Kharkiv : Osnova. 148p.

21. Saussure, F. de, 1977. Kurs obshchey lingvistiki [The course of general linguistics]. Trudy po yazykoznaniyu [Works on Linguistics.]. M.: Progress, - pp. 31-273.

22. Susov, I. P., 1999. Sistemnyye svyazi mezhdu yedinitsami leksikona [System connections between units of the lexicon]. Vvedeniye $\mathrm{v}$ teoreticheskoye yazykoznaniye [Introduction to Theoretical Linguistics]. Retrieved July 10, 2019, from: https://refdb.ru/look/1364945.html.

23. Trier, J.1931. Der deutsch Wortschats un Sinnbezik des Verstandes. Heidelberg, 520 p. 
24. Yermolenko, S.Ya., (ed.), 2001. Ukrayinska mova : Korotkyy tlumachnyy slovnyk linhvistychnykh terminiv [Ukrainian language: A short explanatory dictionary of linguistic terms]. K. Lybid. 224 p.

25. Filin, F.P.,1957.O leksiko-semanticheskikh gruppakh slov [On lexical and semantic word groups]. Yazykovyye issledovaniya. [Language Studies]. Sofia. pp.5-9.

26. Shcheblykina, T.A., 2001. Rol parametrychnykh prykmetnykiv iz prostorovoyu semantykoyu u formuvanni linhvalnoho obrazu svitu [The role of parametric adjectives with spatial semantics in the formation of the lingual image of the world]: Candidate of philological sciences. Kharkiv. $16 \mathrm{p}$.

27. Shchur, H.C., 1974. Teorii polya v lingvistike [Field Theories in Linguistics] M.: Nauka, $256 \mathrm{p}$.

У ДК 81'373-047.22:378.011.3-057.87(045)

DOI:10.31339/2617-0833-2019-2(27)-2-86-90

\section{ФОРМУВАННЯ ЛЕКСИЧНОЇ КОМПЕТЕНЦІЇ СТУДЕТІВ ВНЗ В ПРОЦЕСІ ВИВЧЕННЯ ДИСЦИПЛІНИ «УКРАЇНСЬКА МОВА ЗА ПРОФЕСІЙНИМ СПРЯМУВАННЯМ»}

Прокопович Л.С.

\section{FORMATION OF LEXICAL COMPETENCE OF UNIVERSITY STUDENTS IN THE PROCESSOF STUDYING OF THE DISCIPLINE "UKRAINIAN LANGUAGE FOR PROFESSIONAL"}

Prokopovych Lidia

У статті розглянуто особливості формування лексичної компетениї студентів ВНЗ в прочесі вивчення дисиипліни "Украйнська мова за професійним спрямуванням». Частково описано зміст програми з «Украӥнської мови за професійним спрямуванням» Міністерства науки $і$ науки України, названо найновіші посібники з цієї дисципліни. Висвітлено мету $i$ завдання. 3'ясовано, щуо важливе значення має лексична компетентність майбутніх спечіалістів, щзо пов'язано з фаховою спрямованістю навчання майбутніх психологів, економістів, менеджерів, вчителів $i$ т.д. названо найважливімі лексичні джерела, на які можуть посилатися студенти в процесі вивчення дисципліни» «Українська мова за професійним спрямуванням».

Ключові слова: лексична компетенція, іншомовні лексика, калька, синоніми пароніми.

The article deals with the peculiarities of the formation of lexical competence of university students in the process of studying the discipline "Ukrainian language for professional direction".

The content of the program on "Ukrainian language for professional direction" of the Ministry of Science and Science of Ukraine is partially described, and the latest manuals in this discipline are named. Purpose and objectives are outlined. It is found that the lexical competence of future specialists is important, which is related to the professional orientation of future psychologists, economists, managers, teachers, etc. named the most important lexical sources that students can refer to in the course of studying the discipline "Ukrainian language for professional orientation".

Rules for the use of borrowed vocabulary are formulated and certain warning are used when using the words of the same synonym, since the words synonyms often require an accent in different terms. Definitely, that calculating is one way of enriching the vocabulary of a language. However, in many cases, it causes a lexical language impairment. It is found that the proximity of 